\title{
Analisis Dampak Penerapan Strategi Pengelolaan Terhadap Peningkatan Hasil Pengelolaan Wakaf Uang
}

\author{
Hendra Kholid ${ }^{1 *}$, Ana Mar'a Khonita ${ }^{2}$
}

\section{Abstrak}

Penelitian ini menggunakan metode kualitatif bersifat deskriptif bertujuan untuk menganalisis Strategi Lembaga Global Wakaf ACT dalam melakukan pengelolaan wakaf uang dan untuk mengetahui dampak penerapan rencana strategis terhadap pengelolaan hasil wakaf uang Lembaga Global Wakaf ACT. Hasil penelitian menunjukkan bahwa Pertama, Ada 3 Rencana strategis yang diterapkan oleh Lembaga Global Wakaf ACT yaitu Membuat Ekosistem Program yang menyentuh dari hulu hingga ke hilirnya, Mengelola dana wakaf uang secara profesional, Melakukan evaluasi secara berkala. Kedua, Dampak penerapan rencana strategis terhadap pengelolaan wakaf uang Global Wakaf ACT pada tahun 2017-2018 sangat efektif karena terjadinya peningkatan dalam persentase di tahun 2017 sebesar 6,79\% dan di tahun 2018 sebesar 95,48\%. Namun di tahun 2019 dampak penerapan rencana strategis itu kurang efektif karena terjadinya penurunan presentase sebesar $-21,60 \%$, hal tersebut bisa disebabkan karena permasalahan ekonomi yang berbeda disetiap tahunnya, oleh sebab itu harus dilakukan evaluasi kembali dengan melakukan pembaharuan pada program yang ada.

Kata Kunci: Rencana Strategi; Wakaf Uang; Efektivitas

\section{Abstract}

This study uses a descriptive qualitative method to analyze the strategy of the ACT Global Waqf Institution in managing cash waqf and determine the impact of implementing strategic plan on the management of the ACT Global Waqf Institution's of cash waqf. The results of the study show that First, there are 3 strategic plans implemented by the Global Waqf Institute ACT, namely Creating an Ecosystem Program that touches from upstream to downstream, Managing cash waqf funds professionally, Conducting regular evaluations. Second, the impact of implementing strategic plans on the management of ACT Global Waqf cash waqf in 2017-2018 was very effective due to an increase in percentage in 2017 of $6.79 \%$ and in 2018 of $95.48 \%$. However, in 2019 the impact of implementing the strategic plan was less effective due to a decrease in the percentage of $-21.60 \%$, this could be due to different economic problems every year, therefore it must be re-evaluated by updating existing programs.

Keywords: Strategic Plan; Cash Waqf; Effectiveness

\footnotetext{
${ }^{1}$ Institut Ilmu Al-Qur'an, Jakarta

${ }^{2}$ Institut Ilmu Al-Qur'an, Jakarta
}

Analisis Dampak Penerapan Strategi Pengelolaan Terhadap Peningkatan Hasil Pengelolaan Wakaf Uang 


\section{PENDAHULUAN}

Pemerintah punya perhatian besar tentang Wakaf Uang, adanya pengesahan Undang-Undang Republik Indonesia Nomor 41 Tahun 2004 tentang wakaf dianggap sangat baik karena undangundang ini mengatur semua jenis harta wakaf, baik yang bergerak maupun tidak bergerak. Peraturan Pemerintah (PP) Nomor 42 tahun 2006 tentang Pelaksanaanya, Kepres No. 75/M Th. 2007, Peraturan Menteri Agama (PMA) Nomor 4 Tahun 2009 tentang Administrasi Wakaf Uang, Fatwa MUI no 2 tahun 2002 tentang Wakaf Uang dan beberapa Peraturan Badan Wakaf Indonesia (BWI). Penerbitan undangundang dan peraturan lain yang berkaitan dengan wakaf yang disertai dengan perhatian serius pemerintah dianggap sebagai salah satu faktor yang sangat menguntungkan institusi wakaf ke arah peningkatan prospek ekonomi harta wakaf menuju lebih baik (Lubis, 2010:89). Semuanya bertujuan untuk meningkatkan kesejahteraan perekonomian umat.

Di dunia Indonesia, prospek ekonomi harta wakaf diyakini akan bisa lebih berkembang dan lebih baik jika harta wakaf diaplikasikan pada tempat dan kondisi yang memungkinkan (Lubis, 2010:89). Dalam Al-Qur'an Surah Al-Hajj ayat 77

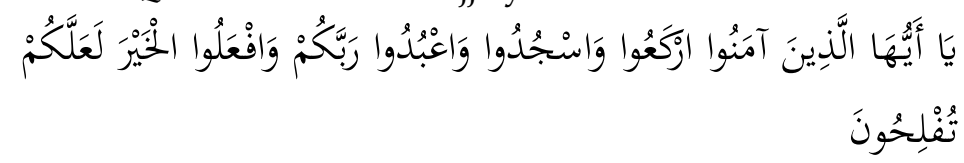

Artinya: "Wahai orang-orang yang beriman, rukuk dan sujudlah kamu dan sembahlah Tuhanmu, serta berbuatlah kebaikan supaya kamu mendapatkan kemenangan".

وَافْعَلُوا الْخَيْر dengan melakukan semua aktifitas yang baik dalam rangka mendekatkan diri (taqarrub) kepada Allah SWT (Al-Shabuni, t.th:300). Tidak ada satu orang pun yang tidak sepakat jika wakaf adalah perbuatan yang baik dan terpuji, melakukannya dalam rangka taqarrub kepada Allah SWT, mendatangkan banyak manfaat bagi umat utama lagi jika dikelola dengan baik, benar profesional dan sesuai dengan aturan yang berlaku di negara ini.

Sudah sejak lama umat Islam di Indonesia mempraktikkan wakaf dalam kehidupan sehari-hari. Namun potensi wakaf itu masih belum termanfaatkan dengan baik. Selain itu, pemanfaatan wakaf

\footnotetext{
20 Hasil Pengelolaan Wakaf Uang
}

Hendra Kholid, Ana Mar'a Khonita 
masih lebih banyak ditujukan di bidang sosial peribadatan seperti pembangunan masjid, madrasah, dan makam. Kemudian Presiden Joko Widodo meluncurkan Gerakan Nasional Wakaf Uang (GNWU) pada 25 Januari 2021, GNWU yang diluncurkan Presiden menandai dimulainya transformasi pelaksanaan wakaf yang lebih luas dan modern (Presidenri.go.id, Februari 2021).

Menurut Direktur Pemberdayaan Zakat dan Wakaf, Kementerian Agama (Kemenag) Tarmizi Tohor, Indonesia memiliki nazir wakaf terbanyak di dunia. Di mana ada sekitar ribuan nazhir perorangan dan 248 nazir wakaf uang. Menurut Bank Wakaf Indonesia (BWI) potensi wakaf uang nasional sebesar Rp180 triliun per tahun, ujar Tarmizi, dalam webinar ISEF di jakarta, Jumat (30/10/2020) (iNews, Januari 2021).

Sejatinya pengelolaan harta wakaf sangat bergantung pada nazirnya. Sehingga produktif atau tidaknya harta wakaf sangat ditentukan oleh kemampuan dan pengetahuan nazir. Dalam hal demikian, pada dasarnya peran nazir sebagai pengelola wakaf tidak hanya sekedar menjaga dan melakukan hal-hal yang bersifat rutinitas, melainkan juga mencari inovasi-inovasi baru dalam rangka mengembangkan dan memberdayakan aset wakaf tersebut. Untuk itu, perlu ada upaya perbaikan yang bertujuan untuk membenahi manajemen wakaf dan menghilangkan sebab-sebab keterpurukan manajemen wakaf akibat ulah nazir dan kelalaiannya (iNews, Januari 2021).

Nazir wakaf telah diatur dalam Undang-Undang No. 41 Tahun 2004 tentang wakaf dengan sangat rinci. Hal demikian menunjukkan bahwa nazir memiliki kedudukan yang sangat penting di dalam Undang-Undang tersebut. Maka jika ada harta wakaf yang tidak produktif, atau harta wakaf yang hilang atau yang dialihkan, maka penyebabnya adalah pada nazir yang kurang mampu menjalankan fungsinya dengan baik (Khosim \& Busro, 2018: 52).

Saat ini di Indonesia ada Lembaga yang konsen dalam mengelola Wakaf yaitu Global Wakaf ACT. Global Wakaf ACT memandang potensi sumber daya wakaf dan sasaran pendayagunaannya setara. Problem peradaban kemanusiaan yang kompleks sebanding dengan keluasan kreativitas manajerial terhadap 
wakaf. Keyakinan ini melahirkan program-program monumental dengan azas komprehensif (Globalwakaf, Januari 2021).

Terdapat Empat produk pilihan wakaf yang disalurkan oleh Global Wakaf ACT yaitu, wakaf pangan, wakaf Pendidikan, wakaf Kesehatan, wakaf ekonomi, dan waqif dapat berwakaf di Global Wakaf ACT pada 2 programnya yaitu wakaf uang atau wakaf melalui uang. Perbedaannya, wakaf melalui uang maka wakif yang menentukan peruntukan wakafnya tersebut. Jika wakaf uang nazhir yang menentukan peruntukkan wakafnya. Saat ini sudah terkumpul sebanyak Rp 233.661.156, nominal dari aset wakaf uang pada Lembaga Global Wakaf ACT (Globalwakaf, Januari 2021). Wakaf uang lebih memungkinkan bagi Global Wakaf untuk mengalokasikan manfaat wakaf sesuai dengan kebutuhan penerima manfaat dalam periode tertentu.

Global Wakaf ACT mengelola wakaf dengan pemahaman makro, pilihan sikap menajerial yang akan terus-menerus melahirkan kreativitas penanganan makro problem kemanusiaan, sebuah stimulan kehidupan yang menggerakkan dan mendinamisasi dakwah yang tiada kenal kata akhir. Dan dengan begitu, wakaf secara signifikan berkontribusi membangun peradaban global menjadi lebih baik.

Dalam publikasinya di sosial media resmi Global Wakaf ACT baik itu melalui website, Instagram, facebook atau twitter mereka selalu mempublikasikan hasil pengelolaan atau pemanfaatan wakaf uang yang dikelolanya melalui program-program yang dimilikinya. Dari Pengelolaannya dan program yang di publikasikan, maka para waqif tergerak hatinya untuk berwakaf uang. Dari pengelolaan dan program tersebut pastinya Global Wakaf ACT memiliki strategi dalam pengelolaan wakaf uang tersebut yang menjadi acuan untuk mencapai sasaran yang mereka tuju yaitu peningkatan hasil pengelolaannya dan reputasi baik dan trust dari masyarakat. Karena strategi yang bagus akan berdampak pada keberhasilan pengelolan wakaf uang tersebut dan juga berdampak pada kesejahteraan ekonomi umat.

\section{LANDASAN TEORITIS}

1. Dasar Hukum Wakaf Uang

a. Al-Qur'an 


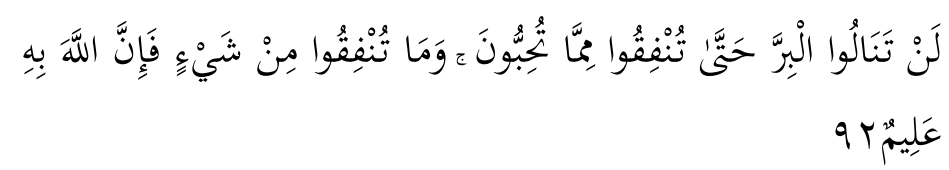

"Kamu tidak akan memperoleh kebajikan, sebelum kamu menginfakkan sebagian harta yang kamu cintai. Dan apa pun yang kamu infakkan, tentang hal itu sungguh, Allah Maha Mengetahui". (Q.S. Ali Imran [3]: 92)

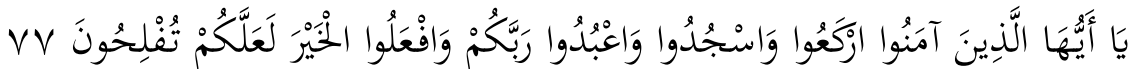

"Wahai orang-orang yang beriman! Rukuklah, sujudlah, dan sembahlah Tuhanmu; dan berbuatlah kebaikan, agar kamu beruntung". (Q.S. Al-Hajj [22]: 77)

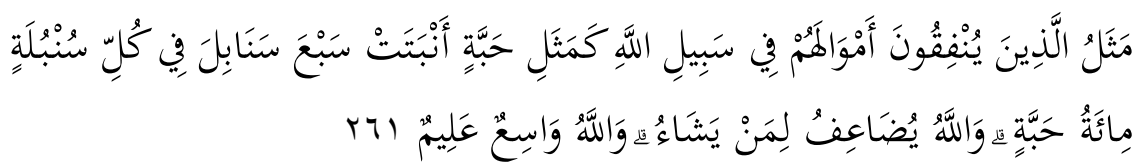

"Perumpamaan orang yang menginfakkan hartanya di jalan Allah seperti sebutir biji yang menumbuhkan tujuh tangkai, pada setiap tangkai ada seratus biji. Allah melipatgandakan bagi siapa yang Dia kehendaki, dan Allah Mahaluas, Maha Mengetahui". (Q.S. Al-Baqarah [2]: 261)

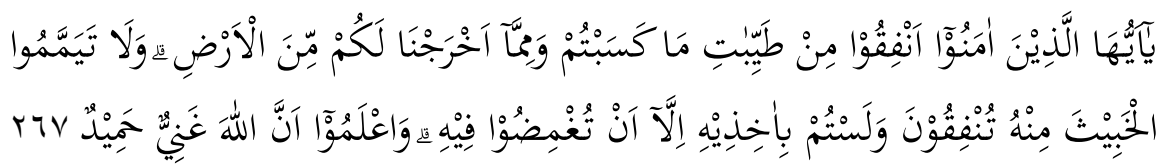

"Wahai orang-orang yang beriman! Infakkanlah sebagian dari hasil usahamu yang baik-baik dan sebagian dari apa yang Kami keluarkan dari bumi untukmu. Janganlah kamu memilih yang buruk untuk kamu keluarkan, padahal kamu sendiri tidak mau mengambilnya melainkan dengan memicingkan mata (enggan) terhadapnya. Dan ketahuilah bahwa Allah Mahakaya, Maha Terpuji". (Q.S. Al-Baqarah [2]: 267)

Ayat-ayat diatas sebenarnya secara eksplisit tidak langsung memerintahkan untuk berwakaf, perintah berwakaf dianjurkan dalam bentuk berinfaq dan melakukan perbuatan yang bertujuan untuk kebaikan bagi sesama.

b. Hadits

Analisis Dampak Penerapan Strategi Pengelolaan Terhadap Peningkatan Hasil Pengelolaan Wakaf Uang 


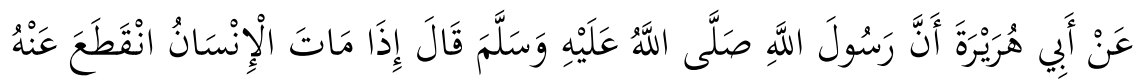

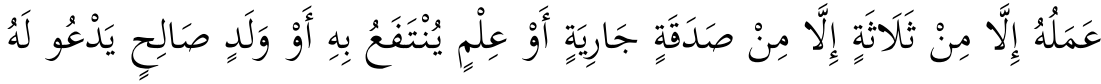

Diriwayatkan oleh Abu Hurairah r.a. sesungguhnya Nabi Saw. telah berkata: "Apabila seorang anak Adam meninggal dunia maka putuslah amalnya kecuali tiga hal: sedekah jariyah, ilmu yang bermanfaat, anak sholeh yang mendoakan orang tuanya". (H.R. Muslim: 3084)

Relevansi hadist ini adalah Shadaqah jariyah diterangkan oleh para ulama dengan nama wakaf.

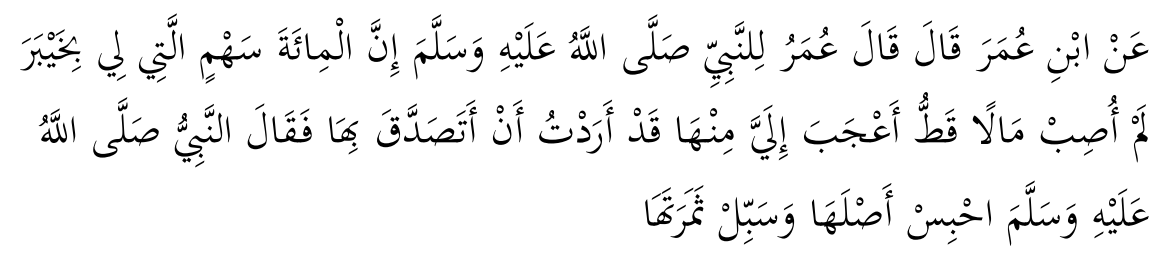

Diriwayatkan dari Ibnu Umar r.a ia berkata, Umar berkata kepada Nabi SAW "Sungguh, aku belum pernah mendapatkan harta yang lebih aku cintai dari seratus saham (tanah, kebun) yang aku dapat di Khaibar. Dan aku berkeinginan untuk bersedekah dengannya." Maka Nabi SAW bersabda, "Tahanlah pokoknya dan jadikan buahnya di jalan Allah". (H.R Al-Nasa'i: 3546)

Dari hadist diatas bahwa praktik pelaksanaan wakaf yang dianjurkan oleh nabi yang dicontohkan oleh khalifah umar ibnu khatab, sangat menekankan pentingnya menahan eksistensi benda wakaf, dan diperintahkan untuk menyedekahkan hasil dari pengelolaan benda wakaf tersebut. Pemahaman praktek pelaksanaan wakaf menurut Nabi bahwa substansi ajaran wakaf itu tidak semata-mata terletak pada pemeliharaan bendanya (wakaf) tapi yang jauh lebih penting adalah nilai manfaat dari benda tersebut untuk kepentingan kebijakan umum.

Berdasarkan Undang-undang No. 41 tahun 2004 tentang wakaf, unsur wakaf terdiri dari; Wakif, Nazhir, harta benda wakaf, ikrar wakaf, peruntukkan harta benda wakaf, jangka waktu wakaf.

a. Wakif, Pada Pasal 7 dan 8, wakif meliputi:

1. Perseorangan

2. Organisasi

3. Badan Hukum 
b. Nazhir, Pada pasal 9 dan 10, Nazhir meliputi:

1. Perseorangan

2. Organisasi

3. Badan Hukum

c. Harta Benda Wakaf

Pada Pasal 15 menjelaskan bahwa harta benda wakaf hanya dapat diwakafkan apabila dimiliki dan dikuasai oleh Wakif secara sah. Pada Pasal 16, Harta Benda Wakaf meliputi:

1. Benda tidak bergerak, meliputi:

i. Hak atas, tanah sesuai dengan ketentuan peraturan perundang-undangan yang berlaku baik yang sudah maupun yang belum terdaftar;

ii. Bangunan atau bagian bangunan yang berdiri di atas tanah;

iii. Tanaman dan benda lain yang berkaitan dengan tanah;

iv. Hak milik atas satuan rumah susun sesuai dengan ketentuan peraturan perundang-undangan yang berlaku;

v. Benda tidak bergerak lain sesuai dengan ketentuan syariah dan peraturan perundang-undangan yang berlaku

2. Benda Bergerak, meliputi:

i. Uang

ii. Logam Mulia

iii. Surat Berharga

iv. Kendaraan

v. Hak atas kekayaan intelektual

vi. Hak Sewa

vii. Benda, bergerak lain sesuai dengan ketentuan syariah dan peraturan perundang-undangan yang berlaku.

d. Ikrar Wakaf

Pada pasal 17, 18, dan 19 menjelaskan bahwa, Ikrar wakaf dilaksanakan oleh Wakif kepada Nadzir di hadapan PPAIW dengan disaksikan oleh 2 (dua) orang saksi. Ikrar Wakaf dinyatakan secara lisan dan/atau tulisan serta dituangkan dalam akta ikrar wakaf oleh PPAIW. Dalam hal Wakif tidak dapat menyatakan ikrar wakaf secara lisan atau tidak dapat hadir dalam pelaksanaan ikrar wakaf karena alasan yang dibenarkan oleh hukum, Wakif dapat menunjuk kuasanya dengan surat kuasa yang diperkuat oleh 2 (dua) orang saksi. Untuk dapat 
melaksanakan ikrar wakaf, wakif, atau kuasanya mcnyerahkan surat dan/atau bukti kepemilikan atas harta benda wakaf kepada PPAIW.

e. Peruntukan Harta Benda Wakaf

Pada Pasal 22, Dalam rangka mencapai tujuan dan fungsi wakaf, harta benda wakaf hanya dapat diperuntukkan bagi:

1. sarana dan kegiatan ibadah

2. sarana dan kegiatan pendidikan serta kesehatan

3. bantuan kepada fakir miskin, anak terlantar, yatim piatu, bea siswa

4. kemajuan dan peningkatan ekonomi umat; dan/atau

5. kemajuan kesejahteraan umum lainnya yang tidak bertentangan dengan syariah dan peraturan perundang-undangan.

\section{HASIL DAN PEMBAHASAN}

\section{Produk Wakaf di Lembaga Global Wakaf ACT (Aksi Cepat Tanggap)}

Global Wakaf ACT menyediakan berbagai produk wakaf, hal itu dilakukan supaya masyarakat dapat dengan mudah berwakaf, tanpa harus memiliki sebidang tanah atau bangunan. Berbagai Produk wakaf yang tersedia di Lembaga Global Wakaf ACT diantaranya yaitu:

\section{Wakaf Pangan}

Pada produk wakaf ini Global Wakaf ACT ingin meminimalisir krisis pangan yang menjadi problem kemanusiaan yang membentang hingga saat ini. Maka membangun ketahanan pangan adalah solusi menghadapinya. Ada beberapa program wakaf pangan yang di buat oleh Global Wakaf ACT antara lain (Globalwakaf.com, Juli 2021):

\section{a. Wakaf Sawah}

Program Wakaf Sawah ini merupakan konsep jaminan pangan masyarakat melalui pengelolaan wakaf dalam bentuk lahan pertanian untuk menghasilkan pangan dengan sistem multi-manfaat, sehingga dapat menghasilkan pangan berkualitas, surplus yang lebih besar dan mampu menopang kebutuhan pangan masyarakat. Wakaf Sawah ini akan menjadi payung dari seluruh aksi untuk membebaskan kemiskinan para petani, untuk menjadikan mereka hidup lebih sejahtera, dan meningkatkan kedaulatan pangan negeri.

Pada program ini Global Wakaf ACT melakukan pengembangan menjadi Program Wakaf Sawah Produktif (WSP) yang merupakan bagian dari Gerakan Sedekah Pangan Nasional. Wakaf Sawah 
Produktif adalah program optimalisasi dana wakaf yang disalurkan khusus kepada petani padi, untuk kebutuhan permodalan usaha tani dalam bentuk pengadaan sarana produksi, sedekah kerja, dan pendampingan. Global Wakaf ACT melalui Wakaf Sawah Produktif melakukan intervensi di tiga aspek, yaitu teknologi pertanian, modal kerja, dan penyerapan hasil panen oleh Global Wakaf ACT. Intervensi teknologi pertanian untuk meningkatkan produksi, modal kerja untuk kebutuhan produksi seperti membeli pupuk dan bibit, kemudian Global wakaf ACT juga menjamin pembelian gabah dengan harga yang menguntungkan untuk petani. Melalui modal kerja Wakaf Sawah Produktif, petani padi diharapkan tidak lagi terjerat perutarangan dan riba.

\section{b. Wakaf Sumur}

Pada program Wakaf Sumur ini, Global Wakaf ACT mengadakan sumber air baru di wilayah kekeringan dengan mencari titik potensi sumber mata air. Wakaf Sumur merupakan salah satu program yang hadir dari pengelolaan dana wakaf. Wakaf Sumur dikelola dalam bentuk penyediaan Sumur beserta kelengkapannya (ketika telah terpenuhi minimal mencukupi untuk 1 sumur) hingga dapat mengalirkan air yang layak dikonsumsi dan dimanfaatkan untuk menopang kehidupan masyarakat khususnya di daerah yang sering dilanda kekeringan.

Program Wakaf Sumur ini tidak hanya untuk di daerah Indonesia, melainkan juga untuk saudara muslim di banyak Negeri lainnya, seperti di Gaza, Afrika, dan yang lainnya. Menjawab kondisi-kondisi yang dialami banyak saudara muslim di berbagai negara, maka Global Wakaf tergerak untuk membangun sumur wakaf di negeri-negeri tempat saudara-saudara muslim tinggal. Tentu saja agar mereka lebih mudah mendapatkan air bersih untuk dikonsumsi dan memenuhi kebutuhan sehari-hari lainnya.

\section{Wakaf Pendidikan}

Pada produk wakaf ini Global Wakaf ACT menjadikan pendidikan menjadi bagian penting untuk memastikan generasi bangsa mendapat pendidikan yang layak demi membangun perabadan yang kuat. Dengan begitu Produk Wakaf Pendidikan ini menyalurkan dana wakaf Anda untuk membangun sarana dan prasarana sekolah, memastikan anak-anak usia sekolah mendapat pendidikan layak

Analisis Dampak Penerapan Strategi Pengelolaan Terhadap Peningkatan Hasil Pengelolaan Wakaf Uang 
meskipun jauh dari akses pendidikan. Penyaluran dana wakaf pendidikan meliputi: Pertama, pembangunan ruang kelas atau sekolah khususnya di pulau-pulau Tepian Negeri. Kedua, memberikan penunjang kegiatan belajar mengajar meliputi meja dan bangku, bukubuku pelajaran dan buku belajar. Selain sarana dan prasarana sekolah, dana wakaf juga akan disalurkan untuk pembangunan masjid atau mushola sebagai pusat edukasi agama dan karakter.

Global Wakaf ACT juga sedang membangun sistem pendidikan berbasis wakaf dengan nama Pesantren Peradaban. Sekolah yang berlokasi di Desa Cintabodas, Kecamatan Culamega, Kabupaten Tasikmalaya ini nantinya hadir untuk membantu anak-anak sekitar memperoleh pendidikan. Selain sarana pendidikan, Pesantren Peradaban nantinya juga akan dilengkapi dengan asrama khusus putra dan putri. Para santri sendiri tidak akan dikenakan biaya selama menempuh pendidikan di Pesantren Peradaban.

Pada Program wakaf Pendidikan Global wakaf ACT juga berkolaborasi dengan GREDU. GREDU ini memiliki tujuan untuk mendigitalisasi sekolah serta meningkatkan kualitas edukasi di Indonesia, perusahaan pengembang aplikasi digital untuk edukasi, GREDU, mewakafkan sebagian dari saham perusahaannya. Keputusan ini tidak terlepas dari tujuan mereka untuk berkontribusi sosial. Bersama GREDU, Global Wakaf ingin mengembangkan dunia pendidikan, tidak hanya di Indonesia saja, tetapi juga secara global. GREDU sejatinya telah membawa kemanfaatan besar dalam dunia pendidikan. Melalui GREDU, murid, sekolah, dan orang tua dihubungkan dalam suatu sistem secara real-time hingga menampilkan hasil dari aktivitas siswa selama di sekolah. Ia berharap dengan adanya Global Wakaf dapat mempercepat kemanfaatan dari GREDU.

\section{Wakaf Kesehatan}

Pada produk wakaf ini Global Wakaf ACT menyediakan berbagai kebutuhan sarana kesehatan. Pada awal diaktivasi, program ini berupa wakaf sarana mobil ambulans beserta obat-obatan untuk mendukung rumah sakit dan klinik dalam pelayanan medis bagi korban konflik kemanusiaan Suriah.

Pada Produk ini tersedia program Armada kesehatan berupa Ambulance Pre-Hospital yang merupakan program bantuan medis kedaruratan. Hadir untuk orang-orang yang kurang mampu dan mereka yang tinggal di daerah terpencil dengan keterbatasan akses 
rumah sakit di Indonesia. Juga menyediakan layanan kesehatan gratis berupa Pertolongan penderita gawat darurat pra Rumah Sakit, dan lainnya.

Selain Program Armada Kesehatan, terdapat juga program yang bernama Wakaf Rumah Sakit, yaitu dengan memberikan pelayanan medis bagi masyarakat yang membutuhkan, ataupun korban konflik kemanusiaan.

\section{Wakaf Ekonomi}

Pada produk wakaf ini Global Wakaf ACT memproduktifkan aset wakaf, dan menjadikan pijakan utama program ini. Awal diaktivasi program ini menggerakkan empat program, yaitu:

\section{a. Wakaf Ternak}

Wakaf Ternak ini menggerakkan perekonomian lewat pemeliharaan dan pembiakan demi kemaslahatan umat, yaitu melalui fattening (penggemukan) dan breeding (pembibitan). Pada program ini Sebagai dukungan ketahanan pangan dan pemberdayaan pesantren, Global Wakaf ACT menghadirkan program wakaf untuk pesantren, yaitu Wakaf Ternak Produktif, program yang ditujukan untuk menggerakkan kemandirian ekonomi pesantren melalui pengelolaan domba yang menjadi ternak wakaf.

Program Wakaf Ternak Produktif berkolaborasi dengan sejumlah pesantren untuk mengembangbiakkan kambing-kambing yang diwakafkan di Lumbung Ternak Wakaf binaan Global Wakaf ACT. Dalam hal ini, pesantren mendapatkan wakaf ternak yang akan dikembangkan sebagai Lumbung Ternak Wakaf berbasis pesantren. Hasil pengelolaan wakaf ternak di pesantren akan dimanfaatkan dan diberikan kembali ke pesantren sekitar untuk dikembangkan kembali sebagai Lumbung Ternak Wakaf lainnya. Program Wakaf Ternak Produktif diharapkan bisa menciptakan kemandirian ekonomi sehingga mampu untuk mengelola ekonomi pesantren sendiri dan lingkungan sekitarnya. Global Wakaf ACT juga berharap semoga domba-domba wakaf yang dikelola oleh Lumbung Ternak Wakaf bisa lebih berkembang dan kemudian bisa menjadi jembatan kebaikan antar pesantren. Jika sudah berkembang, pesantren akan membantu pesantren lain yang belum mandiri dan mampu, sehingga ekonominya akan tumbuh (ACT News, Juli 2021).

\section{b. Wakaf Properti}

Analisis Dampak Penerapan Strategi Pengelolaan Terhadap Peningkatan Hasil Pengelolaan Wakaf Uang 
Pada program ini ditujukan untuk meningkatkan manfaat dari aset wakaf agar mampu berkontribusi di bidang sosial ekonomi serta menopang kemajuan pembangunan suatu daerah. Pengelolaan wakaf dalam bentuk properti, ditujukan untuk meningkatkan manfaat dari aset wakaf. Global Wakaf Tower (GWT) merupakan salah satu contoh program Wakaf Properti, yakni membangun gedung perkantoran bertingkat dengan dana wakaf dan maslahat pengelolaannya didayagunakan untuk kepentingan umat.

\section{c. Wakaf Ritel}

Program ini merupakan hasil dari optimalisasi dana wakaf melalui pengelolaan bisnis, sehingga lebih produktif berkelanjutan dan member manfaat berlipat bagi umat. Sodaqo merupakan brand Wakaf Ritail yang diaktivasi pertama kali pada Juni 2016 dan akan terus dikembangkan di berbagai kota di Indonesia. Wakaf Ritel merupakan integrasi konsep "bisnis dan sedekah".

Ritel Wakaf merupakan program dari Global Wakaf ACT untuk mendukung perekonomian masyarakat. Seperti pembangunan pertama Ritel Wakaf Pesantren Modern Internasional (PMI) Dea Malela, di Lenagguar, Sumbawa, Nusa Tenggara Barat (NTB). Ritel Wakaf Dea Malela menjadi Ritel Wakaf pertama di Sumbawa. Berbeda dari ritel kelontong modern lainnya, modal utama Ritel Wakaf adalah wakaf tunai dari para wakif. Ritel Wakaf merupakan manajemen aset wakaf melalui wakaf tunai. Hadirnya Ritel Wakaf diharapkan menjadi pionir penggerak ekonomi umat di sekitar pesantren (ACT News, Juli 2021).

\section{d. Wakaf Saham}

Program Wakaf saham ini atau surat berharga yang ditujukan untuk memaksimalkan perolehan deviden akan dioptimalkan untuk memberikan manfaat bagi umat. Pengelolaan wakaf saham atau surat berharga yang ditujukan untuk memaksimalkan perolehan deviden (bagi hasil) (Globalwakaf.com, Juli 2021). Sejalan dengan visi Bursa Efek Indonesia (BEI) yang sedang mengembangkan pasar modal syariah sebagai pilihan investasi di Indonesia, wakaf saham diperkenalkan sebagai salah satu inovasi kepada para investor. Para investor tetap dapat mendapatkan return, tetapi juga melakukan kebaikan dengan mewakafkan asetnya atau hasil keuntungannya. Saham yang bisa diwakafkan antara lain saham yang diperdagangkan di bursa dan harus saham Syariah (ACT News, Juli 2021). 
Objek wakaf dapat berupa nominal dari saham yang diwakafkan. Jika nazhir menganggap yang harus diwakafkan sahamnya, maka yang dicatat sebagai wakaf adalah lot saham. Namun, jika nazhir menganggap saham terlalu berisiko karena, misal, aset yang tidak dapat diubah, maka bisa dicatat yang sebagai wakaf itu nilai nominalnya (ACT News, Juli 2021).

Produktivitas wakaf saham atau keuntungan wakaf saham juga bergantung pada nazhir yang mengelola. Maslahat wakaf saham dalam filantropi juga dipengaruhi upaya nazir mengelola aset wakaf. Global Wakaf sebagai nazhir pun berharap wakaf saham dapat meningkatkan kesejahteraan masyarakat.

\section{Strategi Global Wakaf dalam Pengelolaan Wakaf Uang melalui Rencana Strategi}

Rencana strategi yang digunakan Global Wakaf ACT dalam melakukan pengelolaan wakaf uang dapat dilihat berdasarkan hasil wawancara dengan Bapak Renaldi Daniel selaku Head of Strategic Development Program Global Wakaf ACT berikut ini (Wawancara dengan Renaldi Daniel, Head Of Strategic Development Program, Tangerang Selatan, wawancara oleh penulis di Tangerang Selatan, 28 April 2021):

1. "Harus membuat ekosistem program, karena setiap program yang dilakukan harus menyentuh sisi hulu sampai ke hilirnya, akan lebih baik ada ekosistem yang saling mendukung. Sebagai contoh pada program Wakaf Sawah Produktif maka ada satu petani di hulu, petani adalah produsen yang outputnya adalah gabah. Kemudian jika hanya gabah sangat disayangkan jika tidak ada pihak yang melanjutkan, maka Global Wakaf bertindak juga sebagai pembeli gabahnya, bahkan dalam program Global Wakaf Sawah Produktifkami menambahkan Rp 200 harga gabah petani tersebut, jika harga di pasar Rp 4000 maka dibeli Rp 4200, supaya petani mendapatkan kesejahteraan juga, atau Ketika harga gabah turun, Global Wakaf beli dengan harga pasar, yang penting petani mendapatkan untung. kemudian petani outputnya gabah atau padi, dan padi ini diproses maka kami juga bekerja samal bermitra ataupun kami punya penggilingan padi sendiri yang juga dikelola dari dana wakaf, saat ini kami sudah punya 2 lumbung beras wakaf ada di Blora, Jawa tengah, dan Solo, dan beberapa lainnya sifatnya kemitraan. Dengan penggilingan padi lokal, kemudian padinya kita bawa untuk diproses

Analisis Dampak Penerapan Strategi Pengelolaan Terhadap Peningkatan Hasil Pengelolaan Wakaf Uang 
jadi beras, itu menjadi salah satu mata rantainya. Setelah diproduksi maka dibawa ke wakaf distribution center ini adalah salah satu dari program yang tugasnya mendistribusikan beras wakaf gratis, air minum wakaf gratis, ke masyarakat, mustahik, dan santri yang masuk kategori penerima manfaat".

2. "Menjaga supaya Global Wakaf selalu dapat reputasi yang baik dimata masyarakat, yaitu dengan cara Amanah menjaga wakaf yang disampaikan, professional dalam pengelolaannya, sehingga outputnya dapat mendapatkan hasil yang optimal yang hasilnya ini dibagikan dalam bentuk program-progrsm, beras gratis, food truck, dan lainnya. Jadi intinya adalah Global Wakaf ACT harus Amanah dalam mengelola dana wakaf ini, mencegah terjadinya kerugian dan sebagainya".

3. "Selalu melakukan evaluasi dan berinovasi kembali dari setiap strategi yang tidak berhasil, jadi tidak hanya melihat hasil akhir melainkan perjalannyapun harus selalu melakukan evaluasi, kira-kira dalam program ini apa yang kurang, apakah meningkat, jika tidak faktor apa yang tidak menyebabkan meningkat, apakah programnya yang tidak menyentuh masyarakat atau komunikasi yang belum sampai, semua harus dibedah satu-satu, bahwa ada target yang tidak tercapai maka harus melakukan pembenahan kenapa target tidak tercapai dan melakukan inovasi lagi, karena ada kala 1 tahun 1 Triliun maka setiap 2 pekan harus evaluasi, dari grafik kita sudah bisa melihat kenapa pencapaian perpekan, perbulan tidak seusai dengan target, maka harus ada evaluasi terus menerus".

Dari gambar tersebut menjelaskan bahwa Rencana Strategis dalam pengelolaan wakaf uang pada Global Wakaf ACT, dengan membuat Ekosistem Program terlebih dahulu, dalam pembuatan ekosistem program tersebut juga diperhatikan dengan menganalisa problem perekonomian yang sedang terjadi, kemudian melihat peluang apa yang bisa dilakukan oleh Global Wakaf ACT yang kemudian ditemukanlah Problem solving atau solusi dan dari permasalahan tersebut maka tersedialah kebutuhan masyarakat yang dibungkus dalam bentuk program-program. Setelah itu dilakukanlah evakuasi terhadap program tersebut dalam bentuk pengelolaannya. Dalam pengelolaannya Global Wakaf ACT selalu menjaga Amanah setiap wakifnya menjaga wakaf yang disampaikan. Kemudian dikelola dengan professional yang artinya keprofesionalan tersebut yang

32 Hasil Pengelolaan Wakaf Uang

Hendra Kholid, Ana Mar'a Khonita 
nantinya akan menjadi reputasi baik Global Wakaf ACT. Selanjutnya hasil pengelolaannya akan di dibawa menuju distribution center untuk dibagikan kepada yang berhak menerimanya. Selalu berhati-hati supaya tidak terjadi kerugian karena yang dikelola ini adalah Amanah masyarakat yang diberikan untuk kesejahteraan masyarakat lainnya yang kurang mampu. Dengan begitu Global Wakaf ACT akan selalu menjaga kepercayaan masyarakat terhadapnya.

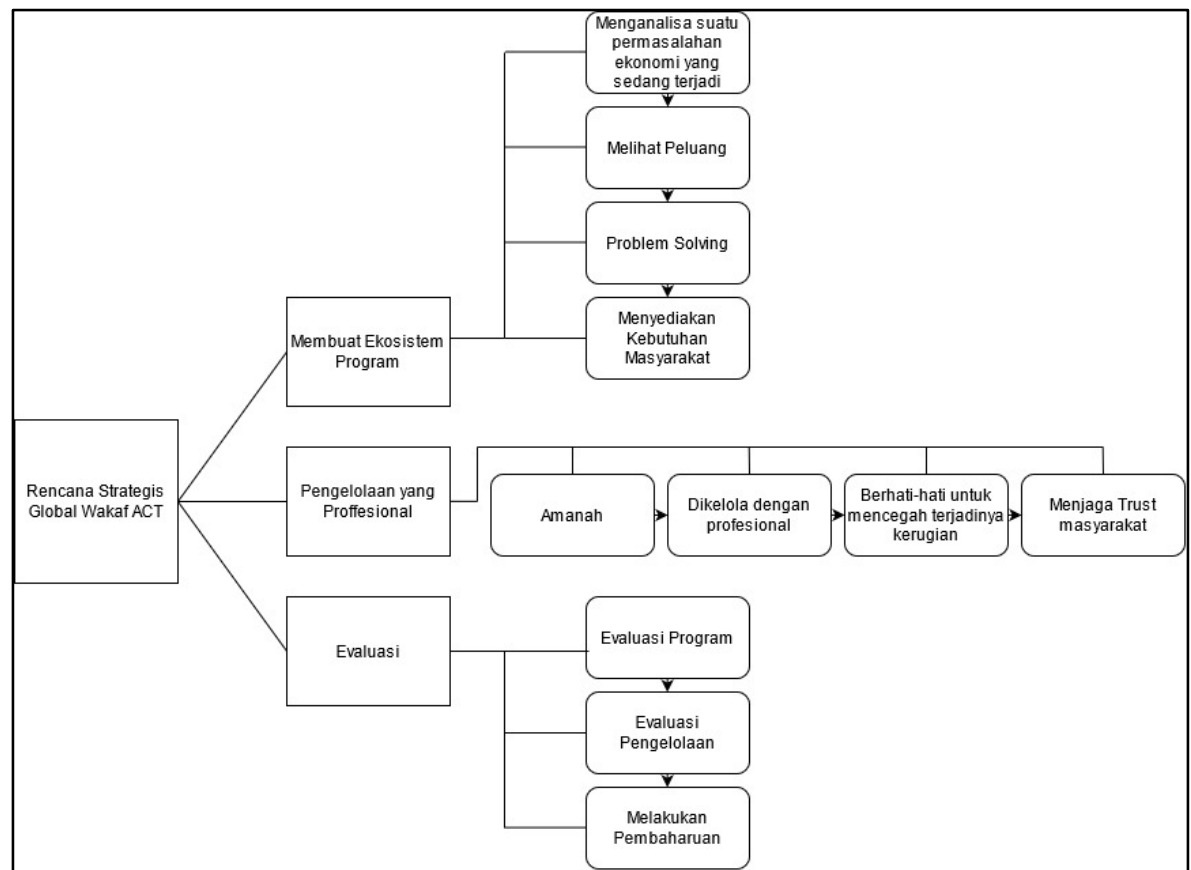

Gambar 1. Skema Rencana Strategis Pengelolaan Wakaf Uang Global Wakaf ACT

Maka dari penjelasan yang telah dijelaskan oleh narasumber, kesimpulannya yaitu Global Wakaf ACT membuat program dengan menggunakan ekosistem program yang mana dari program tersebut dapat menyentuh dari hulu hingga ke hilirnya, dalam pengelolaanya Global Wakaf ACT akan selalu menjaga keprofesionalannya, keamanahannya, dan mencegah dari terjadinya kerugian, kemudian selalu mengevaluasi secara bertahap dari setiap rencana strategi yang dibuatnya, untuk melihat progress yang didapatkan sesuai atau tidak dengan yang diharapkan.

Analisis Dampak Penerapan Strategi Pengelolaan Terhadap Peningkatan Hasil Pengelolaan Wakaf Uang 
Berdasarkan hasil wawancara dengan Bapak Renaldi Daniel selaku Head of Strategic Development Program Global Wakaf ACT Salah satu bentuk evaluasi yang dilakukan global wakaf ACT yaitu:

"Ketika ada kendala dalam pelaksanaan program-program yang ada bahwa masih lemahnya pengetahuan masyarakat kepada wakaf uang, itulah fungsi Global Wakaf untuk terus mengedukasi terhadap masyarakat akan pentingnya wakaf sebagai salah satu instrument ekonomi, dan wakaf sudah terbukti baik secara kontemporer atau saat ini sebagai sumber modal yang paling baik untuk perekonomian suatu bangsa. Buktinya pemerintah sudah mengangkat wakaf, ada sukuk wakaf, wakaf link sukuk. Solusinya untuk menangani kendala tersebut kami mengadakan webinar, sosialisasi, dengan cara dan jalur apapun kepada masyarakat. Kami punya perspektif yang lebih komperhensif yaitu masyarakat bagaimanapun perlu bukti, kita buktikan dengan programprogram tadi supaya jelas apa yang dilakukan oleh Global Wakaf ACT. Kemudian kami menyentuh para kaum milenial, karena saat ini kaum milenial juga memiliki dampak yang besar untuk kedepannya. Dalam menyentuh kaum milenial ini kami membuat program yang baru berjalan 6 bulan ini yang Bernama Santani (santri taruna petani). Program tersebut dibuat karena kami sadar betul petani ini sudah tua maka kami perlu kaum milenial untuk masuk kesektor pertanian, hanya saja ke sektor pertanian yang lebih modern, tidak seperti yang dilakukan oleh orang tua mereka sebelumnya, itu disisi asset nya. Kalo di sisi yang lain, karena mereka suka saham, maka kami punya galeri wakaf dimana kaum milenial yang hobinya di saham mereka bisa berwakaf. Dengan contoh mereka beli 10 lot saham, kemudian 1 lotnya diwakafkan. Dan termasuk event-event lain yang melibatkan kaum milenial". (Wawancara dengan Renaldi Daniel, Head Of Strategic Development Program, Tangerang Selatan, wawancara oleh penulis di Tangerang Selatan, 28 April 2021).

Dari hasil wawancara diatas itulah salah satu bentuk evaluasi yang dilakukan, mereka memberikan problem solving tergantung dari problem yang mereka hadapi. Dengan begitu proses pengelolaanpun terus berkembang. Menurut penulis beberapa kendala yang terjadi dan evaluasi berupa solusi yang diberikan oleh narasumber tersebutpun dalam pelaksanaannya memerlukan dana pengelolaan yang tidak sedikit. Oleh karena itu setiap evaluasi berupa solusi yang dihasilkan Sangatlah menentukan langkah kedepannya. Jika solusi terebut merupakan sebuah program, maka program tersebut bukanlah suatu hal yang hanya sekedar program biasa, melainkan nantinya akan 
menghasilkan sesuatu yang produktif, yang bisa memancing para wakif lainnya juga untuk berwakaf, dengan begitu bisa memberikan dampak untuk kesejahteraan ekonomi umat.

Dalam suatu Perusahaan sangat dibutuhkan rencana strategis dengan tujuan supaya apa yang menjadi target dan tujuannya bisa terwujud. Oleh karena itu Global Wakaf ACT membuat rencana Strategis sebaik mungkin dalam pengelolaan dana wakaf uang supaya setiap dana wakaf uang yang masuk bisa dikelola dengan baik sesuai perencanaannya dan menjadi manfaat baik itu bagi pengelola juga penerima manfaat itu sendiri. Karena rencana strategis yang dirancang dengan sebaik mungkin akan menjadi formula untuk Global Wakaf ACT dalam menjaga trust masyarakat terhadapnya untuk menjadi jembatan setiap dermawan yang ingin mewakafkan hartanya kepada para penerima manfaat dan menjadi Lembaga yang memberikan banyak manfaat dalam menyejahterakan perekonomian umat.

\section{Dampak Pengelolaan Strategi Wakaf Uang di Lembaga Global Wakaf ACT (Aksi Cepat Tanggap)}

Efektivitas pada penelitian ini menitik beratkan keberhasilan sebuah lembaga pada pencapaian tujuannya, progresifitas dan faktorfaktor lain dalam strategi pengelolaan wakaf uang. Global Wakaf ACT menggunakan ekosistem program yang mana ekosistem Program tersebut menyentuh dari hulu hingga ke hilirnya dalam arti bahwa Global Wakaf ACT akan terus memberikan kontribusi kepada masyarakat secara luas, Global Wakaf ACT ingin semua programnya dapat menjadi solusi kemiskinan di Indonesia tidak hanya siaga dalam kebencanaan dan emergency response. Hal ini karena, permasalahan umat yang paling besar dan laten adalah kemiskinan.

Tabel 1. Penerimaan dan Penyaluran Dana Wakaf Uang 2017-2019

\begin{tabular}{c|c|c}
\hline \hline Tahun & $\begin{array}{c}\text { Penerimaan Dana Wakaf } \\
\text { Uang }\end{array}$ & $\begin{array}{c}\text { Penyaluran Dana } \\
\text { Wakaf Uang }\end{array}$ \\
\hline \hline 2017 & $\operatorname{Rp} 4.078 .644 .458,00,-$ & $\operatorname{Rp~} 4.375 .578 .044,00,-$ \\
\hline 2018 & $\operatorname{Rp} 293.769 .378,00,-$ & $\operatorname{Rp} 6.502 .207 .271,00,-$ \\
\hline 2019 & $\operatorname{Rp} 3.822 .727 .627,00,-$ & $\operatorname{Rp} 3.143 .437 .143,00,-$ \\
\hline
\end{tabular}

Sumber: Laporan keuangan ACT 2017-2019

Analisis Dampak Penerapan Strategi Pengelolaan Terhadap Peningkatan Hasil Pengelolaan Wakaf Uang 
Dari tabel diatas dapat dilihat pada tahun 2017 penerimaan dana wakaf uang sebanyak $\mathrm{Rp}$ 4.078.644.458,00,- dikelola dan berhasil disalurkan sebanyak Rp 4.375.578.044,00,- adanya peningkatan dari hasil penerimaan terhadap penyaluran yang artinya dana wakaf yang diterima dikelola sedemikian rupa dengan program ekosistem yang tersedia hingga meningkatkan hasil penyalurannya kepada masyarakat. Begitu juga pada tahun 2018 penerimaan dana wakaf uang sebanyak Rp 293.769.378,00,- dikelola dan berhasil disalurkan sebanyak Rp 6.502.207.271,00,- terjadi peningkatan dalam penyalurannya. Dan pada 2019 penerimaan dana wakaf uang sebanyak Rp 3.822.727.627,00,dikelola dan berhasil disalurkan sebanyak Rp 3.143.437.143,00,- pada tahun ini terjadi penurunan jumlah nominal pada penyalurannya yang dibandingkan dengan penerimaannya. Hal tersebut bisa disebabkan karena permasalahan ekonomi yang berbeda disetiap tahunnya. Maka dari itu pastinya menjadi evaluasi bagi Global Wakaf ACT dalam perencanaan kembali rencana strategis ditahun berikutnya.

Presentase kenaikan penerimaan wakaf dan penyaluran wakaf Global Wakaf ACT:

Rasio efektifitas $=$ Selisih Realisasi penerimaan dan penyaluran

Realisasi Penyaluran

$$
\begin{aligned}
\text { Tahun } 2017= & \frac{\operatorname{Rp} 296,933,586,00,-}{\operatorname{Rp} 4.375 .578 .044,00,-} \times 100 \% \\
& =6,79 \%
\end{aligned}
$$

Tahun $2018=\operatorname{Rp} 6,208,437,893,00$,-

$$
=95,48 \%
$$

$$
\begin{aligned}
\text { Tahun } 2019= & \frac{\operatorname{Rp}-679,290,484,00,-}{\operatorname{Rp} 3.143 .437 .143,00,-} \times 100 \% \\
& =-21,60 \%
\end{aligned}
$$


Tabel 2. Presentase Hasil pengelolaan Wakaf Uang tahun 2017-2019

\begin{tabular}{c|c|c}
\hline \hline No & Tahun & Presentase Efektifitas \\
\hline \hline 1 & 2017 & $6,79 \%$ \\
\hline 2 & 2018 & $95,48 \%$ \\
\hline 3 & 2019 & $-21,60 \%$ \\
\hline
\end{tabular}

Sumber: Hasil olah data, laporan keuangan 2017-2019

Dapat dilihat dari tabel 2 rasio efektivitas atas pengelolaan wakaf uang untuk tahun 2017 sebesar 6,79\% dan mengalami kenaikan pada tahun berikutnya yaitu sebesar 95,48\% tetapi untuk tahun 2019 mengalami penurunan, tetapi secara penerimaan dana wakaf uang lebih besar dari tahun 2018, hanya saja penyaluran pada tahun 2019 minus sebesar $21,60 \%$. Hal itulah yang harus menjadi perhatian lagi dalam perencanaan strategis ditahun berikutnya, dengan terus melakukan evaluasi berkala.

Tabel 3. Data Pengelolaan Program Sumur Wakaf Keluarga untuk saudara sebangsa

\begin{tabular}{|c|c|c|c|}
\hline No. & Jenis program & $\begin{array}{c}\text { Periode } \\
\text { tahun }\end{array}$ & Jumlah \\
\hline 1. & $\begin{array}{c}\text { Pembangunan } \\
\text { Sumur Wakaf } \\
\text { Regional }\end{array}$ & $\begin{array}{l}2015- \\
2021\end{array}$ & $\begin{array}{l}\text { Regional Jakarta, Banten: } 69 \text { titik } \\
\text { Regional Jawa Barat: } 276 \text { titik } \\
\text { Regional DIY Jateng: } 111 \text { titik } \\
\text { Regional Jawa Timur, Bali: } 76 \text { titik } \\
\text { Regional Sumatera Utara: } 23 \text { titik } \\
\text { Regional Sumbagteng: } 51 \text { titik } \\
\text { Regional Sumatera Selatan: } 109 \\
\text { titik } \\
\text { Regional Indonesia Timur: } 96 \text { titik }\end{array}$ \\
\hline 2. & $\begin{array}{c}\text { Pembangunan } \\
\text { Sumur Wakaf } \\
\text { Produktif }\end{array}$ & $\begin{array}{l}2015- \\
2021\end{array}$ & $\begin{array}{l}19 \text { Pertanian } \\
1 \text { Perikanan }\end{array}$ \\
\hline 3. & $\begin{array}{c}\text { Pembangunan } \\
\text { Sumur Wakaf } \\
\text { Konsumtif }\end{array}$ & $\begin{array}{l}2015- \\
2021\end{array}$ & $\begin{array}{l}\text { 157 Desa/Kelurahan } \\
246 \text { Masjid/Mushollah } \\
245 \text { Keluarga } \\
114 \text { Pondok Pesantren } \\
35 \text { Sekolah/Madrasah }\end{array}$ \\
\hline
\end{tabular}

Analisis Dampak Penerapan Strategi Pengelolaan Terhadap Peningkatan Hasil Pengelolaan Wakaf Uang 


\begin{tabular}{c|c|c}
\hline $\begin{array}{c}\text { Jumlah Penerima } \\
\text { Manfaat Sumur } \\
\text { Wakaf }\end{array}$ & $\begin{array}{c}2015- \\
2021\end{array}$ & $\mathbf{5 1 2 . 6 4 0 ~ J i w a ~}$ \\
\hline
\end{tabular}

Sumber: website indonesiadermawan.id

Dari tabel diatas pelaksanaan program sumur wakaf produktif berhasil menyalurkan manfaat dana wakaf melalui program tersebut kepada 512.640 jiwa periode tahun 2015 sampai 2021. Terlihat bahwa dampak pengelolaan wakaf uang yang pada program ini bisa membantu banyak masyarakat yang kekurangan air bersih di berbagai daerah. Dan banyak lagi program lainnya atas pengelolaan

Dari data diatas bahwasanya pengelolaan dana wakaf global wakaf ACT pada 2 tahun berturut-turut menaiki peningkatan, itu bukti bahwa rencana strategis pengelolaan wakaf uang yang di miliki Global Wakaf ACT memiliki efektifitas kepada peningkatan hasil pengelolaan wakaf uang, yang mana hal tersebut sangatlah penting terus dipertahankan dan dikembangkan. Karena dari perencanaan strategis yang matang tersebut yang bisa membantu dan meningkatkan perekonomian dan kesejahteraan umat. Meskipun di tahun 2019 mengalami penurunan dengan $-21,60 \%$ itu sebagai cambuk dan evaluasi bagi Tim Global Wakaf ACT untuk mengevaluasi rencana strategisnya di tahun berikutnya, supaya hal tersebut tidak terulang Kembali.

Kesimpulan yang dapat diambil bahwa dampak penerapan rencana strategis terhadap pengelolaan wakaf uang Global Wakaf ACT pada tahun 2017-2018 sangat efektif karena terjadinya peningkatan dalam presentase di tahun 2017 sebesar 6,79\% dan di tahun 2018 sebesar 95,48\%. Namun di tahun 2019 dampak penerapan rencana strategis itu tidak efektif karena terjadinya penurunan presentase sebesar $-21,60 \%$, hal tersebut bisa disebabkan karena permasalahan ekonomi yang berbeda disetiap tahunnya oleh sebab itu harus dilakukan evaluasi kembali dengan melakukan pembaharuan pada program yang ada. Hal tersebut harus menjadi perhatian besar bagi Global Wakaf ACT untuk ditahun berikutnya supaya tidak terulang Kembali. Penulis berharap penelitian yang saya lakukan ini bisa membantu Global Wakaf ACT untuk kembali mengevaluasi penurunan presentase tersebut.

\section{PENUTUP}




\section{Kesimpulan}

1. Ada 3 Rencana strategis yang diterapkan oleh Lembaga Global Wakaf ACT yang pertama, Membuat Ekosistem Program yang menyentuh dari hulu hingga ke hilirnya. Kedua, Mengelola dana wakaf uang secara professional. Ketiga, melakukan evaluasi secara berkala.

2. Dampak penerapan rencana strategis terhadap pengelolaan wakaf uang Global Wakaf ACT pada tahun 2017-2018 sangat efektif karena terjadinya peningkatan dalam presentase di tahun 2017 sebesar 6,79\% dan di tahun 2018 sebesar 95,48\%. Namun di tahun 2019 dampak penerapan rencana strategis itu kurang efektif karena terjadinya penurunan presentase sebesar $-21,60 \%$, hal tersebut bisa disebabkan karena permasalahan ekonomi yang berbeda disetiap tahunnya, oleh sebab itu harus dilakukan evaluasi kembali dengan melakukan pembaharuan pada program yang ada.

\section{Saran}

Berdasarkan hasil kesimpulan dari kajian pembahasan ini maka, ada beberapa saran yang dapat dijadikan pertimbangan yang perlu penulis sampaikan, yaitu:

1. Bagi lembaga yaitu untuk melakukan evaluasi terhadap penurunan presentase pengelolaan wakaf uang pada tahun 2019 dan menemukan problem solving yang tepat dan efektif supaya ditahun-tahun berikutnya tidak terulang kembali.

2. Penulis berharap karya ilmiah ini supaya bisa dijadikan penelitian lebih lanjut oleh penulis lain.

\section{DAFTAR PUSTAKA}

Al-Haitami, Ibnu Hajar. (1983). Al-Fatawa Al-Kubra Al-Fiqhiyyah. Beirut, Daar Al-Fikr.

Al-Jamal, Ahmad Muhammad Abd al-Ahzim. (2007). Al-Waqf al-Islami fi at-Tanmiyah Al-Iqtishadiyyah al-Mu'ashirah. Kairo: Dar As-Salam. Al-kabisi, Muhammad Abid Abdullah. (1977). Ahkam al-waqf fi al-syariah al-islamiyah, Juz I. Baghdad: Matba'ah al-irsyad.

Al-Naisaburi, Imam Abi al-Husain Muslim ibn al-Hajjaj al-Qusyairi. Shahih Muslim. Juz VIII. Beirut: Dar al-Fikr. 
Anggito, Albi \& Johan Setiawan. (2018). "Metodologi Penelitian Kualitatif". Cet. Ke 1. Sukabumi: CV Jejak.

Asiyah, Siti Nur. (2019). Analisis Strategi Penghimpunan Dana dan Pengelolaan Wakaf Uang Pada Pelayanan Kesehatan di BMT Safinah Klaten Jawa Tengah. Skripsi. Institut Agama Islam Negeri Surakarta.

Az-Zuhaili, Wahbah. (1985). Al-Figh al-Islami wa Adillatuh. Beirut: Dar al-Fikr.

Badan Wakaf Indonesia. Peraturan Badan Wakaf Indonesia tentang Pedoman Pengelolaan dan Pengembangan Harta Benda Wakaf, Peraturan BWI No. 01 tahun 2020, BN No. 825 tahun 2020.

Badan Wakaf Indonesia. Peraturan Badan Wakaf Indonesia tentang Tata Cara Pendaftaran Nazhir Wakaf Uang, Peraturan BWI No. 02 tahun 2010, BN tahun 2010.

Departemen Ekonomi dan Keuangan Syariah - Bank Indonesia. (2016). Wakaf: Pengaturan dan Tata Kelola yang Efektif. Jakarta: Departemen Ekonomi dan Keuangan Syariah - Bank Indonesia.

Huda, Miftahul. (2015). Mengalirkan Manfaat Wakaf (Potret Perkemb.angan Hukum dan Tata kelola Wakaf di Indonesia). Bekasi: Gratama Publishing.

Imam, Muhammad Kamaluddin. (1999). Al-Washiyah wal-waqf fi al-islam Maqashid wa qawa'id. Iskandariyah: An-Nasyir al-Ma'arif.

Indonesia, Peraturan Pemerintah tentang Pelaksanaan UndangUndang Nomor 41 tahun 2004 tentang wakaf, PP Nomor 42 Tahun 2006, LN No. 105 tahun 2006.

Indonesia, Undang-Undang tentang Wakaf, UU Nomor 41 Tahun 2004, LN No. 159 tahun 2004.

Ja'far, Khumedi. (2019). Analisis Pendapat Imam Mazhab Tentang Wakaf Tunai dan Implementasinya di Indonesia. Jurnal ASAS. Vol. 11.

Kasdi, Abdurrahman. (2014). Potensi Ekonomi Dalam Pengelolaan Wakaf Uang di Indonesia. Jurnal IAIN Kudus. Vol. 2(1).

Khosim, Ali dan Busro. (2018). Konsep Nazhir Wakaf Profesional Dan Implementasinya di Lembaga Wakaf Nu Dan Muhammadiyah. Jurnal UIN Sunan Gunung Djati Bandung. Vol. 11(1).

Lubis, Suhrawardi K. et. al. (2010). Wakaf dan Pemberdayaan Umat. Jakarta: Sinar Grafika dan UMSU Publisher. 
Majelis Ulama Indonesia. Fatwa Majelis Ulama Indonesia tentang Wakaf Uang, Fatwa MUI tahun 2002.

Menteri Agama, Peraturan Menteri Agama tentang Administrasi Pendaftaran Wakaf Uang, PMA No. 4 tahun 2009, BN No. 129 tahun 2009.

Mukti, Arief Wibawa. (2018). Strategi Pengelolaan Wakaf Tunai Pada Tabung Wakaf Indonesia. Skripsi Universitas Islam negeri Syarif Hidayatullah Jakarta.

Munthe, Iqbal Harfi. (2018). Analisis Strategi Pengelolaan Wakaf Uang Pada Global Wakaf cabang Medan. Skripsi Universitas Islam Negeri Sumatera Utara Medan.

Nasution, M. E. (2018). Peran Badan Wakaf Indonesia (BWI) dalam Pengembangan Wakaf di Indonesia. Jurnal Wakaf dan Ekonomi Islam.Vol. 1(1).

Qahaf, Mundzir. (2006). Al-Waqf Al-Islami; Tatawwuruhu, Idaratuhu, Tanmi-yyatuhu. Cet. II. Syiria: Dar al-Fikr Damaskus.

Qudamah, Syeikh Al-Imam Al-Alamah Mauqifuddin Abi Muhammad Abdullah Ibn Ahmad Ibn. t.th. Al-Mughni, Juz.6. Beirut: Daar AlIlmiah.

Renaldi Daniel, Head of Strategic Development Program, Tangerang Selatan, wawancara oleh penulis di Tangerang Selatan, 28 April 2021.

Rusydiana \& Rahayu. (2019). Bagaimana Strategi pengembangan wakaf tunai di Indonesia? Jurnal Ekonomi dan Bisnis Islam. Institusi penerbit Universitas Airlangga. Vol. 5(1).

Sābiq, Al-Sayid. (1971). Figh al-Sunnah. Jilid III. Bairut : Dar al-Kitab al'Arabi378.

Su'ud, Muhammad Abu. (1997). Risalah fi Jawazi Waqf al-Nuqud. Bairut: Dar Ibn Hazm.

Zahrah, Muhammad Abbu. (1971). Mudharat Fii Al-Waqf. Beirut: Daar Al-Fikr Al-Arabi. 